\title{
INTERCULTURAL THEATER AND THE LOCAL CONTEXT OF RECEPTION Lady Macbeth 2016 and the South Korean Presidential Scandal
}

\author{
Seokhun Choi \\ University of Seoul \\ shchoi2524@uos.ac.kr
}

\begin{abstract}
This essay investigates the relationship between intercultural performance and the sociopolitical context of reception by drawing parallels between Tae-sook Han's 2016 changguk adaptation of her own Lady Macbeth and the recent presidential scandal of South Korea. The discourse of intercultural performance has focused on directorial vision and the political dynamics between the source and target cultures, while the local context of reception and its impact on the overall meaning of the work have relatively been overlooked, particularly from a diachronic perspective. Lady Macbeth revolves around the court physician's psychotherapy sessions for the eponymous heroine, who is haunted by the memories of her past crimes and eventually choked by guilt. While major critics of the play have interpreted the play as a feminist or humanist drama, the scandal challenges such sympathetic views of the heroine due to the play's strong evocation of allegations brought against then-President Geun-hye Park and her confidante Soon-sil Choi. Previously understood as a woman or Everyman that the spectators could identify with, now the queen seems to have become a symbol of corruption and immorality. The play's political subtext is amplified by the play's changguk form whose satire and traditional music contribute to the audience's purgation of han. Holding more immediate relevance and broader appeal to the local audience than before, the new version of Lady Macbeth demonstrates how an extraordinary socio-political context can transform an intercultural performance into a national drama for the local audience.
\end{abstract}

\section{Keywords}

Geun-hye Park; han; intercultural performance; Lady Macbeth; scandal; Sewol; South Korea; Soon-sil Choi; Tae-sook Han 


\begin{abstract}
About the Author
Seokhun Choi holds a PhD in Theatre from the University of Kansas and is currently Assistant Professor in the English Department at the University of Seoul. He has widely published on contemporary American and Korean theatre and popular culture, and his essays have appeared in several Korean and international journals including Journal of American Drama and Theatre, Ecumenica: Journal of Theatre and Performance, and Theatre Research International. He is also a co-editor of the 2017 special issue of Cultural Studies Review on media, mobilities, and identity in Asia.
\end{abstract}

Kritika Kultura 33/34 (2019/2020): 89-110

(c) Ateneo de Manila University

<http://journals.ateneo.edu/ojs/kk/> 


\section{INTRODUCTION}

In 2016, South Korea was catapulted into a monumental political turmoil that has left an indelible scar on the nation's democratic history. The so-called Geun-hye Park scandal, or Soon-sil Choi Gate, centers on Park's unsatisfactory performance as president and her confidante Choi's involvement in government affairs. ${ }^{1}$ Choi's political clout was first hinted at by Kwan-chun Park, a former Civil Affairs administrator of the Blue House, who said that President Park was actually only third in power, following Choi and her ex-husband Yoon-hoe Chung during a prosecutor's interrogation of his alleged disclosure of classified documents. Donga Daily reported his statement in the news article published on 7 January 2015, but it was not taken seriously at that time since it was apparently too wild a claim to make and Choi was not known to the public then (Jang and Choi). About a year and a half later, Choi's name resurfaced with TV Chosun's 26 July 2016 report on Park's senior staff's coercive fundraising efforts for MI-R Foundation and K-Sports Foundationtwo corporate-sponsored organizations promoting Korean culture and sports whose de facto owners and beneficiaries are suspected to be Park and Choi (Jung). It has been revealed that much of the foundations' money was used to advance the equestrian career of Choi's daughter Yoo-ra Chung, who turned out to have gained special favors in her high school and college as well. More unsettling was that Choi, a long-time friend of Park's who does not hold any official government title, was not only given access to government documents but also informally advised the former President on her public duties. These findings shocked and incensed the general public who had expected charismatic leadership and a higher level of moral integrity from the emblematic figure of Korean conservative politics. At the same time, the scandal reignited the controversy about the government's inept response to the Sewol ferry tragedy, a disaster that resulted in the loss of three hundred four civilian lives in 2014. In major cities across the country, a million protesters took to the streets and held candlelight demonstrations every weekend for six months to demand for a thorough investigation of the scandal and for Park's immediate resignation. Much to the relief and joy of the outraged citizens, both the Parliament and the Constitutional Court came out with decisions that would allay their anger and disappointment; the first female president of the country became the first president to be ousted in the history of Korean democracy. At the center of the scandal is a non-bureaucrat woman who allegedly tried to manipulate the head of state in her Machiavellian pursuit of power and privilege: the protagonist of the national drama more commonly referred to as "Soon-sil Choi Gate" or "Soon-sil Choi kookjungnongdan [monopoly of national administration]" than "Geun-hye Park scandal."

In December 2017, the same month that the Parliament overwhelmingly voted to impeach Park, another drama - this time, in the literal sense-featuring a female 
protagonist who sought unmerited power was mounted at the National Gugak Center. Although the playwright and director Tae-sook Han did not make any plot changes for the 2016 changguk (a modern variation of Korean traditional opera pansori) adaptation of her own Lady Macbeth from the previous straight (i.e. nonchangguk) versions performed since 1998, the new version is endowed with much more profound and immediate socio-political significance for the contemporary Korean audience than before by the extraordinary context of reception-an important factor often overlooked or taken for granted in intercultural performance scholarship. Below, I will first provide a brief introduction to the 2016 Lady Macbeth and the genre of changguk. Then I move on to draw parallels between the play and the Park scandal and explain how their relationship challenges the previous understandings of the play and what implications the new interpretation holds for the contemporary discourse of intercultural theater. In tandem with the political reading, I will also analyze how the play's intercultural aesthetics contributes to its satirical and cathartic function in relation to the han of the Korean people living in the so-called "Hell Chosun," a popular neologism encapsulating the serious socioeconomic problems of the country today. The performance analysis is based on my attendance at the performance of the changguk Lady Macbeth at Woomyun-dang, National Gugak Center, on 22 December 2016.

\section{THE REBIRTH OF LADY MACBETH AS INTERCULTURAL CHANGGUK}

Han's 2016 changguk adaptation of Lady Macbeth is a notable case of intercultural theater which can be defined as "the meeting in the moment of performance of two or more cultural traditions" (Holledge and Tompkins 7). Based on her attendance at the 2008 production and borrowing Carl Weber's term, Korean Shakespeare scholar Yee-yon Im regarded the play as transcultural rather than intercultural since it "deconstructs and transcends foreign or indigenous culture to create something new" while making no localizing or hybridizing attempts. For Im, Lady Macbeth, unlike other Korean Shakespeare adaptations written and directed by Yountaek Lee and Tae-Suk Oh, displays "Han's lack of interest in the nationalist agenda of reviving tradition through theatre" (24). This observation, however, is no longer valid for the 2016 version, which transplanted the play into a Korean traditional art form.

The word changguk is a compound of chang ("singing" in the pansori style) and guk ("drama") and began to be used in the 1930s, although the particular dramatic form is believed to have appeared in the 1900s after the construction of the first indoor theater in Korea, Hyomnyulsa, by royal sponsorship (Paek 25). It is difficult to pin down changguk since there is no unanimous consensus on its 
origin and development. However, it is widely held that changguk derived from pansori and received influences from Chinese opera and the Japanese dramatic genres of kabuki and shinpa-thus, changguk in itself is arguably an intercultural performance genre-to go through the following changes (Yeon-ok Jang 96). First, whereas pansori is performed by only one singer (changja) who plays all characters including the narrator, changguk presents multiple performers playing different roles and a narrator-singer called dochang who, similar to the Greek chorus, offers explanations and comments on the action while staying outside of it as a third party. Secondly, pansori relies on symbolic and formalized movements called pallim but changguk acting is generally realistic. Thirdly, while pansori is traditionally performed outdoors in an open and flexible setting, changguk is usually performed in an indoor theater with a clear division between the stage and the audience. Despite these formal differences, changguk retains the profound emotional appeal and satirical humor of pansori. As in pansori, traditional music and chang augment the affective dimension of changguk, allowing the audience to release their own han-"the fundamental aesthetic concept in Korean traditional folk music and dance" (Yeon-ok Jang xxii) - as a result of empathy with the characters (Paek 25859). Also, changguk uses similar black humor to question the status quo and subvert the existing social hierarchy (Paek 261).

While director Han believed in this emotional and satirical effect of changguk in its traditional form, she made further alterations in her 2016 Lady Macbeth to increase its appeal to the contemporary Korean audience. Most lines are sung rather than spoken in a hybrid singing style that combines chang and Western aria to make the play "a fusion gugak (traditional music) drama" (Tae-hyung Song). In lieu of Young-Ran Lee's objet art which made a vital contribution to the play's initial critical success, the channguk features a dochang and an "intercultural" orchestra comprised of Korean traditional drums, a kayagum (a zither-like string instrument with 12 strings), and a contrabass - the only Western instrument included for its low pitch to set an appropriate tone for the play's serious themes. With these new elements taken from traditional Korean culture, what Im previously thought of as "a successful case of 'trans-culturation"' was reborn as an intercultural performance (24).

While these formal elements altogether lend aesthetic and cultural significance to the 2016 production as an intercultural experiment, what makes the play particularly interesting to the local audience is the peculiar socio-political context in which it was produced: a national drama involving a couple of women in power. In fact, Han's Lady Macbeth is not the first Korean Shakespeare play adapted into changguk, nor is it the first changguk that Han directed. As early as the 1950s, Chungsil Hongsil [Blue Thread and Pink Thread] and Heukjinjoo [Black Pearl], changguk adaptations of Romeo and Juliet and Othello respectively, were performed 
by women changguk troupes. More recently, a changguk version of Romeo and Juliet was produced by The National Changguk Theater of Korea in 2009. Han also formerly directed The National Changguk Theater's productions of Nongae (2001), Janghwa and Hongryun (2012), and Dante's Divine Comedy (2013). However, none of these, I would argue, had the degree of immediate political significance that Lady Macbeth now has owing to its relevance to one of the most unsettling political events in modern Korean history.

\section{FROM FEMINIST DRAMA TO POLITICAL SATIRE: PARALLELS BETWEEN THE PARK SCANDAL AND LADY MACBETH}

Lady Macbeth revolves around the court physician's psychotherapy sessions for the eponymous heroine, who is haunted by the memories of her past crimes and eventually choked by guilt. Like Shakespeare's original tragedy and the earlier versions of the play, the changguk explores the moral issue of "the evil that results from a lust for power" (Knights 39). However, the 2016 production gains more political significance for the local audience since the central themes of power, manipulation, and guilt surrounding a female character powerfully evoke the presidential scandal. Here, the two main points of comparison are, first, Lady Macbeth's provocation of Macbeth's treason and Choi's alleged "manipulation" of Park for her personal benefits and, secondly, Lady Macbeth's lack of maternity and compassion for human lives and the controversy about Park's responsibility in the Sewol tragedy.

As in Shakespeare's Macbeth, the idea of "equivocation" is central to Lady Macbeth in its portrayal of human greed and guilt (McCoy 27). The action unfolds on a bare and dimly lit proscenium stage with tilted wooden panels serving as stairs leading to an elevated area in the back. The orchestra is located downstage right and remains visible to the audience throughout the show. As the play begins, Lady Macbeth (played by Eun-hae Chung), wearing a white dress, is sleeping on the stairs in dim blue light, and the court physician (played by Dong-hwan Chung, who also plays Macbeth) and three courtiers in black costumes playfully approach and examine her. Then they see a pile of flour lying in front of her and begin to mold it into different objects including a dung ball, which they pass to each other, and a snake. The symbolism of tilted stairs, black and white costumes, the abject object of dung, and the snake-a traditional symbol of Original Sin referred to by Lady Macbeth herself when she gives the following advice to her husband later, "look like th' innocent flower, But be the serpent under't" (I.v.64-65)-broaches the themes of corruption and equivocation from the beginning. ${ }^{2}$ In particular, the dung, the snake, and Lady Macbeth's dress all contradict the conventional meaning assigned to the white color to suggest that things are not as they appear to be. The equivocal character of Lady Macbeth is what the dochang's opening song alludes 
to: "What is that? Human or ghost? Witch or beauty? Fair is foul, and foul is fair." Whereas these questions are asked of the Weird Sisters in Macbeth, Lady Macbeth is the object of the inquiry in Han's adaptation, which thus conflates the queen with the supernatural beings who stir Macbeth's lust for power and ultimately lead him to commit heinous crimes.

Similar questions arose concerning Choi's identity and Park's image when the Choi scandal was first revealed to the public. Most headlines in newspapers and magazines began with the question "Who is Soon-sil Choi?" since no one knew or was willing to admit their knowledge of her. This question was also a question about Park's identity for her dependence on the non-politician woman of a dubious moral and social standing was in conflict with her public image as an independent, charismatic leader taking after her late father, former President Chung-hee Park (1917-1979). The relationship between Choi and Park is complicated and goes back about forty years when Park first met Soon-sil's late father Tae-min Choi, "a Korean Rasputin" and shamanistic leader of a small syncretic cult known as Youngse-gyo [the Church of Eternal Life] (Min-hye Ko). This meeting is comparable to the first encounter between Macbeth, yet-to-be-king, and the three witches, who prophesied his kingship. It is said that Tae-min won Park's heart by convincing her that her late mother Mrs. Yook, who had been killed by an assassin who had actually aimed at her father Chung-hee, appeared in his dreams to tell him to assist her daughter Geun-hye to be the leader of whole Asia (Yong-rae Cho 37). Park, then a 23-year-old college student who did not know much about the world and was struggling with the loss of her mother, came to trust Tae-min. After Chunghee was assassinated in 1979, Tae-min and his fifth and favorite daughter Soon-sil, who is said to have inherited her father's spiritual gift, became Park's caretakers, even gaining control of her finances and thereby accumulating a great wealth for themselves (CBS Hyun-jung Kim's News Show). Soon-sil, four years Park's junior, worked closely with Park for the "New Heart Movement," a social purification movement Tae-min founded, and cared for Park as her friend and mentor through Tae-min's death in 1994, until Park became a politician and, finally, the President of South Korea.

To the consternation of Korean citizens, Park herself confirmed her intimate relationship with Soon-sil during her public address on 4 November 2017. Park introduced Choi as "a person who stood by me in the most difficult period of my life," admitting that she had sought some personal advice from Choi concerning political matters while denying most allegations of Choi's illegal involvement in politics and her abuse of power in raising funds for the foundations. During the Constitutional Court impeachment trial held on 19 January 2017, Park's secretary Ho-sung Chung testified that Choi is "an officially non-existent person who quietly provides assistance behind the scene so that no one knows" (Ji-yon Han). While 


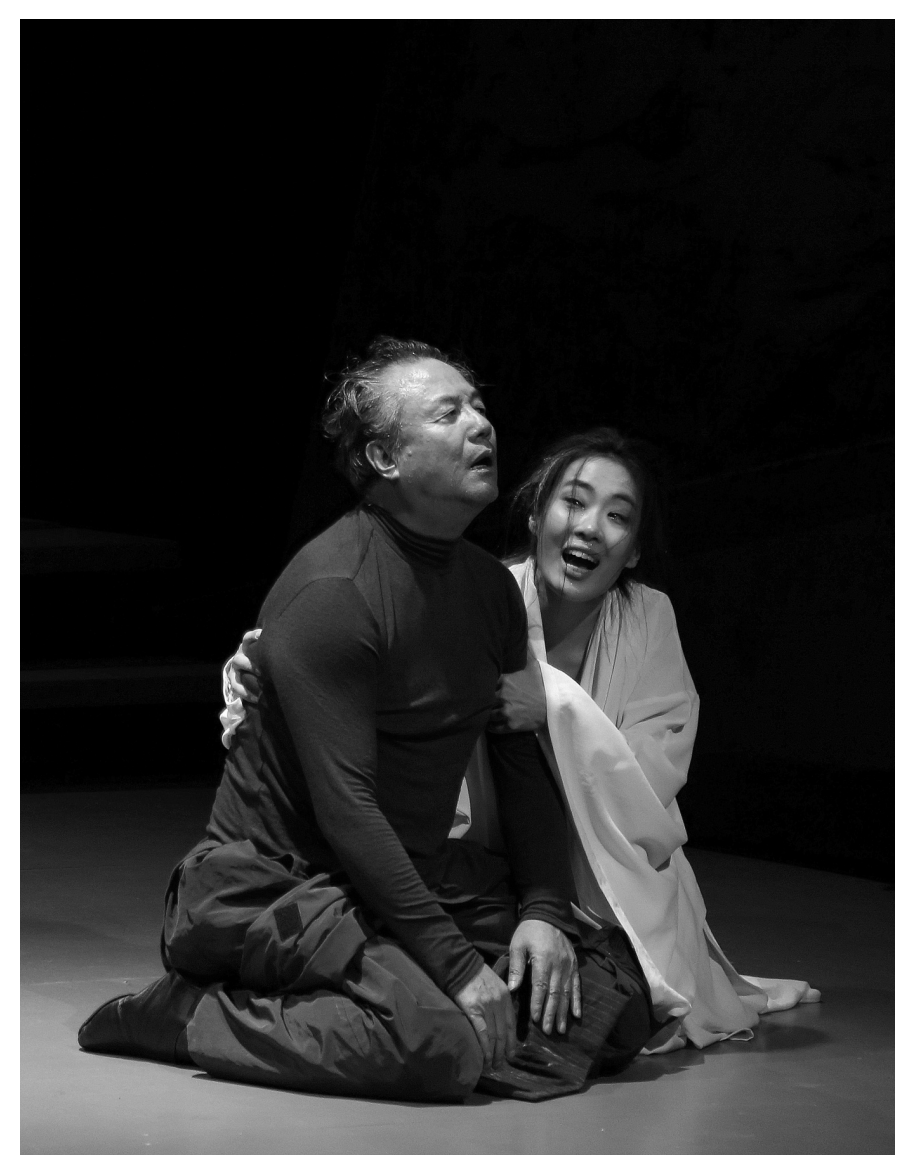

Figure 1. Lady Macbeth (Eun-hae Chung) is trying to persuade her husband (Dong-hwan Chung) to carry out their usurpation scheme. Photo by Je-hoon Jang. Courtesy of Tae-sook Han.

there are conflicting accounts of the relationship between the Parks and the Chois and much of the personal lives of Tae-min and Soon-sil remains unknown, it is certain that Soon-sil met Park through her father Tae-min, became very close to her after their parents died, and exerted influence on Park's administrative decisions to a notable extent. For the majority of Koreans, the scandal was an astonishing disclosure of the huge gap between what they expected the President to be and who she really was.

The main difference of Lady Macbeth from Shakespeare's play is that the former shifts the central focus to Lady Macbeth's role as the manipulator of her husband. In the scene where Lady Macbeth and the courtiers reenact her memories, she goads her doubtful husband to carry out their usurpation plot with her famous speeches taken from Macbeth (I.vii). And then the couple have sex with her on top, which is "clearly illustrative of Lady Macbeth's leading role in Duncan's assassination" 
(Shim 67). After this, the three courtiers start hand-painting the left white wall with mud to rhythmical drumbeats, which symbolizes the couple's past sins including the murder of Duncan. The scene reaches its climax when the regicide is finally committed by Macbeth offstage, and the courtiers run circling around Lady Macbeth, asking her what happened and crying "Treason." Here, the blocking suggests that Lady Macbeth is more than an accomplice to the murder; although she herself does not hold much political or physical power, she has controlled the whole usurpation scheme behind the scene.

The power dynamics between Lady Macbeth and her husband are comparable to the relationship between Choi and Park. As defenders of Park have argued, it is probably not uncommon for people in public offices to rely on some secret aides who provide unofficial assistance and enjoy some privileges in return. However, what sets the scandal apart from other similar cases in modern Korean history is the scale of Choi's involvement despite her humble qualifications and dubious moral character. Choi doesn't have any academic or professional background in politics and once falsely claimed to have earned her MA and $\mathrm{PhD}$ in Child Education from Pacific States University in Los Angeles although she does not even hold a college diploma. Nevertheless, Choi is known to have advised Park on numerous public matters ranging from Park's fashion to public address scripts to personnel decisions. She has also been convicted of using Park's secretaries to coerce several conglomerates including Samsung to contribute funds to MI-R and K Foundations. According to Sung-han Lee, former Secretary General of MI-R Foundation, it was actually Choi who told President Park what to do and there was nothing Park could decide by herself without Choi's permission (Kim and Ryu). These testimonies shocked the public who could not understand Park's dependence on the unqualified friend of hers when she was surrounded by the most intelligent and talented people in the country. Park's former supporters famously complained, "we voted for Park, not Choi."

In conjunction with the idea of manipulation, the child, "perhaps the most powerful symbol" in Macbeth (Brooks 31), serves as another important link between the play and the presidential scandal. In the recollection scene described earlier, Lady Macbeth says, "I have given suck, and know / How tender 'tis to love the babe that milks me. / I would, while it was smiling in my face, / Have plucked my nipple from his boneless gums / And dashed the brains out, had I so sworn as you / Have done to this" (I.vii.54-59). This passage has confused Shakespeare scholars since it is unclear whether she had a child before or whose baby she fed, but the point seems to show her inhuman character and defiant rejection of the maternal role conventionally assigned to women. According to Han, Eun-hae Chung, who played the title role, interpreted the lines with the assumption that the character had never had a child before. ${ }^{3}$ Indeed, Chung's Lady Macbeth speaks the lines 
without any suggestion of maternity and human warmth. Later, Lady Macbeth says to her irresolute husband who is afraid of failure, "We, childless, have nothing to be afraid of," emphasizing their childlessness.

The motifs of motherhood and infanticide take on a great significance in relation to the scandal surrounding Park, a "childless" spinster who has been accused of the dereliction of her presidential duty to protect the lives of the youths lost in the Sewol ferry disaster. On 16 April 2014, MV Sewol, a passenger ferry sailing from Incheon to Jeju, sank off the southwestern coast of South Korea due to cargo overload, causing the deaths of about three hundred people on board, mostly high school students on a school trip. The Coastguard and the National Security Office, not to speak of the captain and crew who have been found guilty of murder, have been harshly criticized for their incompetence and slow response, and the blame was ultimately laid on Park. In particular, her critics have demanded a clear explanation of her activities during the so called " 7 missing hours," the critical period stretching from 10 am, when she received the first report on the accident, to 5:15 pm, when she finally showed up at the Central Disaster and Safety Countermeasures Headquarters on the day of the tragedy. The Blue House adamantly refused to disclose the information on the pretext that the President's whereabouts were classified information, and this puzzling excuse and Park's reticence exacerbated the controversy, leading to a number of speculations; some suggested that Park was holding a cult ritual with Choi and others claimed to have found evidence of Park's receiving a cosmetic treatment. It took more than two years before the Blue House, under the pressure of the scandal, belatedly posted an official explanation for those seven hours on their web site in November 2016 with the title "On the Day of Sewol Disaster: These Are the Facts." The gist of the explanation was that Park made a couple of direct rescue orders on the phone and did all she could and that the delay was mainly caused by the media's erroneous report that everyone was saved (Bo-eun Kim). The online posting, however, never convinced the skeptics who criticized her failure to carefully investigate the circumstances and take the initiative; the Constitutional Court also concluded that Park did not earnestly perform her public duty on that occasion, although it was not one of the reasons factored in its ruling to dismiss her from office. What should be noted here is that, in the popular rhetoric against Park, her lack of leadership was often associated with her lack of maternity-which is ironic given that she had often been promoted as a "maternal leader" or "National Mother" in her political career (Kang 210-11; Ahn 90-94). It is not very difficult to find online comments that ascribe Park's unsatisfactory response to the tragedy to her single status, and one of the surviving parents once bluntly asked, "President Park, do you not understand how we feel because you've had no child?" (Newsis). In the eyes of her critics, the Sewol incident attests to Park's lack of maternity as well as of leadership. 
Even before the opening of the changguk, newspapers and magazines such as Asia Economy Daily, NEWSIS, and Auditorium: Monthly Music and Performing Arts Magazine pointed out the play's thematic link with the scandal (Min-seo Cho; Bum-joon Ko; Lee and Kim). Han was often quoted as saying that the play bears resemblances with the present political situation, although she had not really known what she was getting herself into until the show was almost ready to open concomitantly with the outbreak of the scandal. The particular context of reception, I argue, significantly affects the meaning of the play to challenge the previous interpretations. As Im has already pointed out, most reviews of Lady Macbeth prior to the changguk production were concerned with the feminist politics of the play although Han herself has repetitiously denied having particularly "feminist" motives for her adaptation. For instance, Young-Joo Choi, while praising the creative aesthetics of the play she saw in 2000, considered it as a failed feminist drama since Lady Macbeth dies a villain who fails to find her true self, which makes it difficult to identify or sympathize with her (183). Jung-soon Shim, who saw the play in the same year, situated the play in the genealogy of Korean Shakespeare adaptations that tackle gender issues and, like Choi, viewed the play as an addition to Han's oeuvre "through which Han implicitly demonstrates a feminist orientation" (64). Shim made a more positive assessment of Lady Macbeth than Choi did for the protagonist "purges her Han through the shamanistic ritual of Gut and passes into the other world for good" (70). Here, Shim defines han as "the Korean national ethos, which is traditionally associated with rather negative emotions such as frustrated desire, resentment, regret, and a sense of loss and sorrow" and interprets Lady Macbeth's struggle in terms of the patriarchal oppression of women in traditional Korean society (65). Nevertheless, Shim ultimately finds the play's representation of the female protagonist problematic since Han "maintains the male gaze consistently throughout the play" (70). Thus, the play, according to these views, failed as a feminist drama, even though it was far from Han's intention to make a feminist heroine of Lady Macbeth.

For Im, who saw the 2008 production of Lady Macbeth at the Seoul Arts Center, the feminist interpretative tendency surrounding the play is "symptomatic of politicized academic discourse" (25). Instead, she proposes to go beyond the gender divide with a "non-ideological" reading of the play, which, according to her, "embodies the same universal issue of ambition and guilt represented by Macbeth in Shakespeare's play" (26). Previously an Everywoman of ambivalent feminist politics, Lady Macbeth is now an Everyman that anyone could identify or sympathize with, and Han's play thus appeals "not as political propaganda, but as humanist theatre" (Im 26). While Im's reading offers an alternative to the feminist interpretation, this universal view disregards the local specificity of the target culture which plays an essential role in the formation of meaning. 
Despite their differences from each other, these major criticisms of Lady Macbeth all make sympathetic attempts to understand the female protagonist as representing women or humans. What is overlooked in these views is the peculiarity of Lady Macbeth as an extraordinary individual who would go to the great lengths she did to acquire power, not to speak of her lofty social position as the queen. Furthermore, not many people would be capable, and even proud, of the horrendous violence against new-born babies that she claims to be. In short, her audacity, determination, and cruelty rather set her apart from ordinary people or women in general than make her one of either group; she is a peculiar character with an extraordinary mentality, strong desires, and a will to power, who only happens to be a woman. This critical understanding seems to make more sense now, at least as far as the 2016 changguk is concerned, primarily because of the newly acquired context of reception, which led performance columnist Il-song Kim to say: "There is little difficulty in seeing the witches as a metaphor of shamanism or Tae-min Choi and greedy Lady Macbeth as Soon-sil Choi. Above all, Macbeth, manipulated by the witches and his wife to usurp, represents no one else than the President."

\section{INTERCULTURAL THEATER, LOCAL CONTEXT OF RECEPTION, AND THE KOREAN AFFECT OF HAN}

Given the political magnitude of the Park scandal and its immediate relevance to the play, it would be difficult to deny its significant influence on the meaning of 2016 Lady Macbeth. However, the importance of local context has been overlooked in the discourse of intercultural theater which has revolved around theater practitioners directly involved in the creative process, most notably directors such as Peter Brook, Eugenio Barba, Jerzy Grotowski, Richard Schechner, and Ariane Mnouchkine. For instance, Patrice Pavis observes that every intercultural relationship is "determined by the purpose of the artists and cultural mediators who undertake its adaptation and its transmission," thus emphasizing the active role that artists play in the making of intercultural theater (Intercultural Performance Reader 16). In the more recent essay titled "Intercultural Theatre Today," Pavis situates the works of Oriza Hirata, Robert Lepage, Guillermo Gomez-Pena, and Brook in the broad context of globalization to discuss how the notion of interculturalism "goes through a crisis" due to blurred cultural boundaries (7). There are some limitations to Pavis's view. Besides maintaining his focus on directors, he also fails to take different local contexts into account. Erika Fischer-Lichte disputes the rampant universal view of intercultural performance, since it "ignores the various functions of each case and even the question of useful comparison between them," and calls attention to differences between individual cases (31). Fischer-Lichte's comparative approach complements Pavis's general theory in terms of globalization. Nevertheless, the scope of her analysis is also limited to directors such as Brook, Robert Wilson, and Tadashi Suzuki, as if she equated their stated goals with the actual outcome. 
What is missing in these discussions of intercultural theater is the local context of reception, which is beyond the creators' or any else's control, as instanced by the heated controversy surrounding Brook's adaptation of the eponymous Hindu epic Mahabharata. While Brook's intercultural experiment "received overwhelming critical acclaim" from Western audiences (Croyden), postcolonial critics such as Daryl Chin and Una Chaudhuri called it a form of "cultural imperialism" and "cultural rape" (qtd. in Hutchison 58). Most famously, Rustom Barucha has harshly criticized it as "one of the most blatant (and accomplished) appropriations of Indian culture [.... within an orientalist framework of thought and action" (68). There is in fact little to wonder about these severe criticisms given India's 190-year-long history of colonization by the British Empire; it was the particular local context that led the postcolonial critics to view Mahabharata, which occurred only 38 years after Indian independence, with suspicion and skepticism regardless of Brook's intention. The case of Mahabharata demonstrates that neither the director nor the critics are in control of the meaning of a performance and that there is sometimes a critical perspective shared by the local audience.

Likewise, Lady Macbeth's history of reception shows that there is not always a correlation between the directorial vision and the critical interpretation. While the most popular narrative of the play's origin has it that Han wanted to retell Shakespeare's tragedy from a woman's perspective-a widespread understanding that has been aggrandized as a feminist manifesto, thereby fostering the dominant feminist interpretations of the play, it is traceable farther back to a more artistic and circumstantial reason. The idea of rewriting Macbeth into a woman-centered play first occurred to Han when she was directing a student production of Macbeth at Soodo Women's University (now co-ed Sejong University) in Seoul a few decades ago. Han and the college students performed the play in English without changing the original script, with female students playing all male parts-an interesting reversal of the cross-gender casting practice in the days of Shakespeare. Although Han thought of it as a decent student production, she on the other hand deeply felt the lack of female roles in the original play. While this experience happened decades before she finally wrote and directed Lady Macbeth in 1998, Han recalls it as the first inspiration to rewrite Macbeth into a women-centered play. The main purpose of her adaptation then, simply put, was to create a strong female part by giving a more prominent role to the notorious female character who she thought was left alienated in Shakespeare's male-dominated narrative. In short, Han did not write Lady Macbeth with such overtly political or grandiose aims as transforming the Shakespeare play into a feminist propaganda or finding the universal truth that transcends cultural differences. Political satire was not her agenda, either, when Han first conceptualized changguk Lady Macbeth. She just wanted to recreate the play in a Korean traditional art form for mostly aesthetic reasons. It was only after 
the scandal broke out-when the rehearsal was already in progress-that she found the strong connection between the two.

From a political perspective, the play's satire performs a significant cathartic function for the contemporary Korean audience. As mentioned earlier, the central action of Lady Macbeth is the psychotherapy sessions that the protagonist undergoes. However, what actually happens on stage can more accurately be described as a forced confessional or mockery, torture, and punishment on the pretext of talking cure. Theater critic Min-sook Song, who saw the 2008 revival at Seoul Arts Center, observed that Han did not present Lady Macbeth as a character with agency or rewrite Shakespeare's tragedy from the character's point of view; according to Song, the focus of Han's adaptation is on the doctor's attempt to cure her by means of a "psychodrama" session rather than her fall (171). Granting that psychotherapy is still the play's central motif, the notion of "psychodrama" seems misleading as far as the 2016 production is concerned, since none of the court physician and courtiers display a genuine intention to cure the queen or any warmth towards her. Rather, they try to make her confess her sins by repeatedly asking her to remember and talk



Figure 2. Lady Macbeth (downstage center) as the object of the court physician (upstage center) and the courtiers' (clockwise from left; Hyung-hoon Lee, Jin-hee Park, and Kyum-min Kwon) gaze. Photo by Je-hoon Jang. Courtesy of Tae-sook Han. 
about what she did as if they were prosecutors interrogating a suspect. They even mock her smiling as she suffers from guilt and nightmares throughout the play.

Lady Macbeth is a far cry from tragic overreachers such as Marlowe's Tamburlaine and Dr. Faustus whose ambition is endowed with some humanist magnitude, mainly because the play focuses on her fall by beginning in medias res, where Lady Macbeth has already begun to pay for the consequences of her crimes. While always looking confident with her husband, she constantly worries about failure when she is left alone and is deprived of sleep after the murder. The audience hears her charismatic speeches and sees the scene of Macbeth's (offstage) regicide as in the original play, but they are all but a reenactment of the past. What the audience mostly sees in the "now" of the play is Lady Macbeth's fear and anxiety. In the last scene, one of the courtiers becomes a snake, which symbolizes her guilty conscience, and entangles her body to choke her. She resists but is soon subdued and cries, "we have been carried by the wave of doom, our destiny made us sin, led to a situation where dying is better than living." The physician admonishes her by saying, "don't attribute it to fate," implying that she

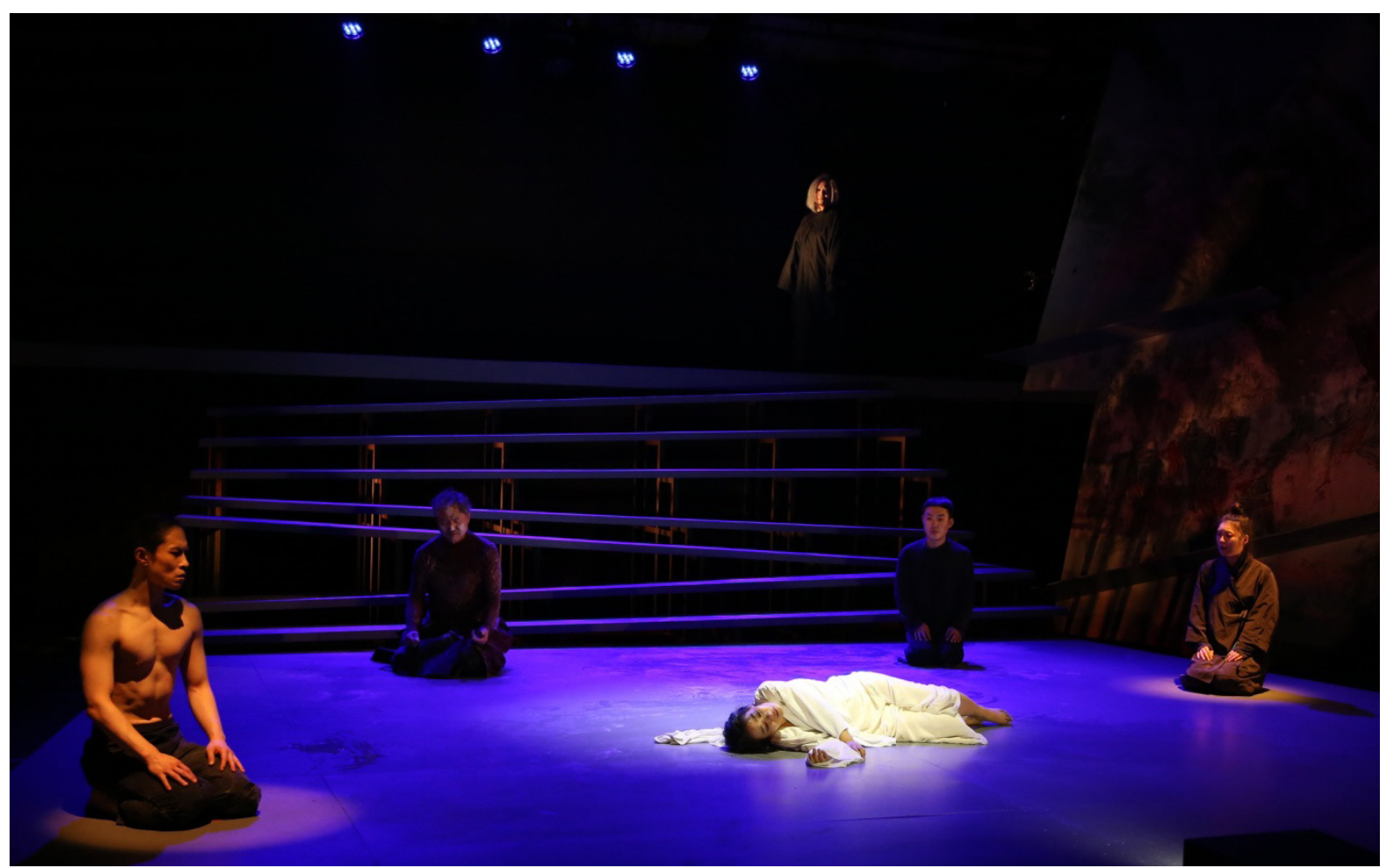

Figure 3. Lady Macbeth suffers from guilt and passes out. Dochang (Kyung-ae Yeom) appears upstage to sing the closing narration. Photo by Je-hoon Jang. Courtesy of Tae-sook Han. 
herself is to blame. Lady Macbeth retorts, "what right do you have to harass me?" and then loses consciousness. ${ }^{4}$ Anxious and afraid, questioned and mocked by her attendants, Lady Macbeth remains as a pathetic figure of criticism and derision throughout the play. She arouses little sympathy since the play represents her in such a way that she appears to deserve the fate. More importantly, the character's evocation of the recent scandal seems to make it more difficult to feel pity for her.

From a feminist perspective, Shim saw Lady Macbeth's destiny as representing the han of the older generations of Korean women who "had no alternative but to resign themselves to their destinies, to endure and persist in their hard lives (70). However, this oppressive environment is no longer widely experienced by women in contemporary Korean society, and the 2016 version seems more geared towards the han of general audiences regardless of gender, namely the "deep sense of injustice and social inequality which the minjung [the mass of the people] suffer from in their everyday lives" (Reyes 161). Yeon-hee Cheon explains that one of the main historical sources of han is the domestic issue of class, which created an immobile hierarchy not just between men and women but also between the noble class and the lower class (123-34). In Korea today, which has been paying for the consequences of its "compressed modernity" since the 1997 IMF crisis (Chang 47), controversy about social class and unequal distribution of wealth arises on a daily basis and the issues of severe competition, unemployment, and decreasing social mobility - a reminder of the social caste of Chosun Dynasty (1392-1897) - have led the younger generation to call the country "Hell Chosun." Especially, the notion of fair competition has come under suspicion since the winners are usually geumsoojuh (people born with a gold spoon in their mouths) rather than those who simply have worked hard on their own but was not lucky enough to have their parents' generous support. According to a 2015 report by the Korea Institute for Health and Social Affairs, this assumption is true; unlike for the Industrial Generation (born between 1940 and 1959), parents' educational background and wealth have a considerable impact on the educational and income level of the Information Generation (born between 1975 and 1995) (Yeo 62). The inheritance of parents' social status is a major deterrent for social mobility and integration in the contemporary Korean society and has been a major source of han for the people who do not have the "privilege" of having well-educated and/or wealthy parents.

The revelation of the unfair advantages gained by the Choi family has shocked and dismayed the majority of Koreans, particularly those who identify themselves as huksoojuh (those born with a clay spoon). The Choi family's wealth is estimated to be about 235 million dollars, most of which is alleged to have been illegally acquired (Se-jeong Kim). Choi bribed her daughter's high school teachers and college administrators so Chung could graduate from high school in spite of her many absences and enjoy special privileges from Ewha Woman's University, one of 
the oldest women's universities in the country. At the official request of the Korean Ministry of Education, Chung's high school diploma and college admission were both canceled in December 2016, and Choi has been found guilty of bribery and sentenced to three years in prison. Chung also received a great amount of athletic sponsorship from Samsung and Choi was convicted of extorting the donation in February 2018. For many Koreans, these reports are a bitter confirmation of their long-held suspicion that the social system is unfair and favors those who are born to wealthy parents or know someone in power. In this social context, Lady Macbeth, I argue, performs a significant socio-cultural function to appease their han. Watching Lady Macbeth's internal struggle and her ultimate fall, the local audience would experience a profound feeling of catharsis.

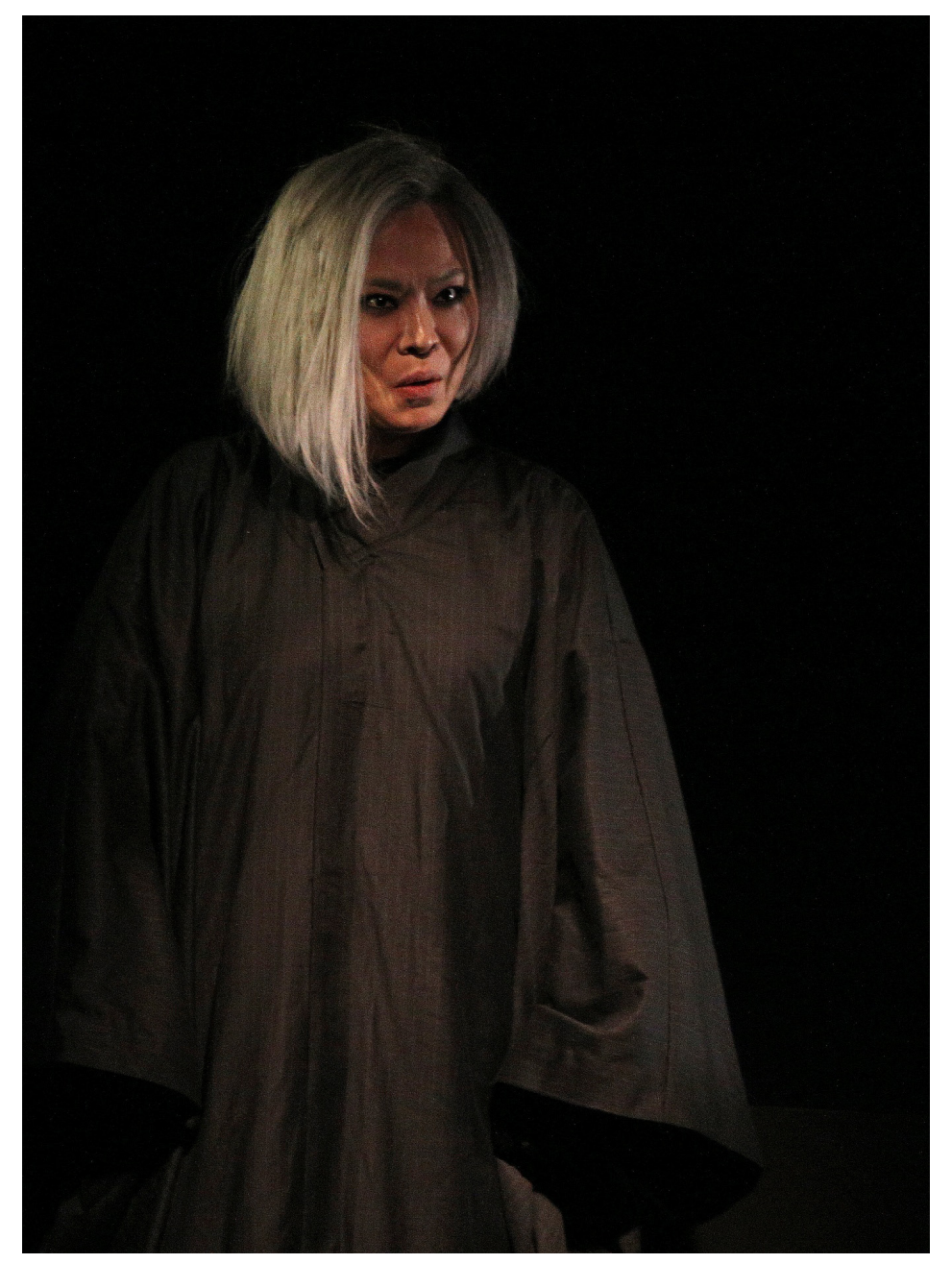

Figure 4. A close-up image of dochang. Photo by Je-hoon Jang. Courtesy of Tae-sook Han. 
Here, the dochang plays a crucial role to the audience's purgation of han as the voice of people. According to Marshal Pihl, pansori "strives to reflect everyday life and so mirror the realities of [the] listeners' lives, the suffering and lamentations of [the] characters are frequently less in service of the plot than of an audience's need for catharsis" (5-6). Heather Willoughby adds that this cathartic process is "intensified by the use of particular harsh and rough vocalizations, or sound qualities, utilized in the genre," which creates the "Sound of Han" (20). Changguk, employing the same traditional music and the same vocal style, has the same affective power as pansori and induces active emotional participation in, rather than cerebral engagement with, the action (Paek 260-61). In Lady Macbeth, it is primarily through the dochang that the audience hears this "Sound of Han," as her chang narrations frame the entire action and help maintain a critical perspective towards the Macbeths. The play closes with the dochang's singing over the queen's dead, or unconscious, body: "Futile candles, go out. Life is but a walking shadow." Here, the metaphorical meaning of the candle is obvious (i.e. the queen's life), but it also evokes the thousands of candles lighted by Korean protesters since the outbreak of the scandal. The dochang's lugubrious and bitter ending song seems to echo the voice of outraged Korean people, marking the end of a national drama revolving around a Korean "Lady Macbeth."

\section{CONCLUSION}

Unlike the conclusion of Lady Macbeth, the ending of the scandal was not immediately known. It was only on 13 February 2018-about 15 months after her indictment-that Soon-sil Choi was found guilty of bribery, influence-peddling, and extortion to be sentenced to 20 years in prison as a result of her first trial. And it was two months later that the public heard the outcome of Park's trials for her eighteen charges in total: 24 years in prison. The tedious legal process put many people, their critics and defenders alike, on the edge. In this respect, the foremost social significance of Lady Macbeth would be that it responded to the psychological and emotional needs of the contemporary Korean audience who desperately wanted to see the guilty punished.

As changguk, Lady Macbeth answers Sung-Hee Jeon's call to create changguk that speaks to contemporary issues and concerns for its further popularization (429). As a piece of intercultural theater, the play is a solid proof of its socio-cultural value since what is originally a canonical English drama has been transformed into a political satire that "inevitably plays an important part in bringing into the open what are the burning issues of the time" to reaffirm Martin Esslin's definition of theater as "the place where a nation thinks in public in front of itself" (101). At the 
center of this transformative process lies the local context of reception as its satirical subtext was greatly amplified by the disclosure of the scandal involving the first female president of the country and her informal advisor who tried control politics behind her. The case of Lady Macbeth shows that the significance of intercultural theater cannot be reduced to aesthetic concerns or the practitioner's vision; rather, a particular context of reception can change what might appear as an innocent cultural experiment into a national drama that performs an important sociopolitical function in the target culture, to remind us of the famous Shakespeare quote which seems pertinent to the conclusion of Lady Macbeth: "All the world's a stage [.... Last scene of all, / That ends this strange eventful history, / Is second childishness and mere oblivion, / Sans teeth, sans eyes, sans taste, sans everything" (As You Like It II.vii. 139-166). 


\section{Notes}

1. Choi's original first name was Pil-nyo, which she changed to Soon-sil and then to the current official name Suh-won. Since she is most commonly referred to as Soon-sil Choi, I will use this name throughout the paper to avoid confusion.

2. A significant portion of Lady Macbeth is a direct Korean translation of lines from Shakespeare's Macbeth. When such is the case, I will use the original English text and give the act/scene/line numbers in parentheses. All textual references to Macbeth in the essay come from The Riverside Shakespeare. Line quotes without parentheses are my own translations.

3. Personal interview with author. Unless otherwise indicated, all references to Taesook Han in the essay derive from this interview.

4. During the interview, Han told me that she wanted to leave it unclear whether Lady Macbeth dies or not, adding that she could not let her die quickly without suffering enough. 


\section{Works Cited}

Ahn, Shi-sung. Maternal Politics Save the Nation. Seungyonsa, 2006.

Bae, Kyung-hee. "Lady Macbeth, the Changguk." The Musical, no. 16o. 16 Dec. 2016, www. themusical.co.kr/Magazine/Detail?enc_num=jG68Bo46QCM6ulIWrJ6Hgg\%3D\%3D. Accessed 16 June 2017.

Barucha, Rustom. Theatre and the World: Performance and the Politics of Culture. Routledge, 1993.

Brooks, Cleanth. The Well Wrought Urn: Studies in the Structure of Poetry. Dobson, 1949.

CBS Hyun-jung Kim's News Show. "Geun-ryung Park Says First Lady Yook Warned About Tae-min Choi." No Cut News. 1 Nov. 2016, www.nocutnews.co.kr/news/4677607. Accessed 7 June 2017.

Chang, Kyung-Sup. "Compressed Modernity and Its Discontents: South Korean Society in Transition." Economy and Society, vol. 28, no. 1, 1999, pp. 30-55. doi: 10.1080/03085149900000023.

Cheon, Yeon-hee. “The Characteristics of 'Sagim' of Korean 'Han." Chonbuk University Institute for Intercultural Communication Symposium, vol. 2013, no. 12, 2013, pp. 123-28.

Cho, Min-seo. "'Our Voice' That Speaks of the Miserable End of Power Abuse: Changguk Lady Macbeth." Asian Economy Daily. 23 Dec. 2016, www.asiae.co.kr/news/view. htm?idxno=2016122210070007746. Accessed 17 July 2017.

Cho, Yong-rae. Another Family: Tae-min Choi, Sun-ee Im, and Geun-hye Park. Modern Archive, 2017.

Choi, Young-Joo. "Lady Macbeth: Psychodrama Made of Light, Sound, and Form." Performance \& Theory, vol. 2, 200o, pp. 181-200.

Croyden, Margaret. "Peter Brook Transforms an Indian Epic for the Stage." The New York Times. 25 Aug. 1985, www.nytimes.com/1985/o8/25/arts/peter-brook-transforms-anindian-epic-for-the-stage.html?pagewanted=all. Accessed 10 June 2017.

Esslin, Martin. An Anatomy of Drama. Hill and Wang, 1976.

Evans, G. Blakemore, et al., editors. The Riverside Shakespeare. $2^{\text {nd }}$ ed., Houghton Mifflin, 1997.

Fischer-Lichte, Erika. "Interculturalism in Contemporary Theatre." The Intercultural Performance Reader, edited by Patrice Pavis, Routledge, 1996, pp. 27-40.

Han, Ji-yon. "Hosung Chung Says, 'Soonsil Choi Is a Secret Helper, Things Got Wrong When She Was Exposed to the Public." SBS News. 19 Jan. 2017, news.sbs.co.kr/news/ endPage.do?news_id=N1004000143\&plink=COPYPASTE\&cooper=SBSNEWSEND. Accessed 20 June 2017.

Han, Tae-sook. Personal interview. 16 May 2017.

Holledge, Julie, and Joanne Tompkins. Women's Intercultural Performance. Routledge, 2000.

Hutchison, Yvette. “The 'Dark Continent' Goes North: An Exploration of Intercultural Theatre Practice through Handspring and Sogolon Puppet Companies' Production of Tall Horse." Theatre Journal, vol. 62, no. 1, 2010, pp. 57-73. 
Im, Yee-yon. "Beyond the Gender Divide: Looking for Shakespeare in Han Tae-Sook's Lady Macbeth." New Theatre Quarterly, vol. 32, no. 1, 2016, pp. 19-30.

Jang, Kwan-suk, and Woo-yeol Choi. "[Exclusive] Kwan-chun Park's Absurd Lecture on 'Power Hierarchy." dongA.com. 7 Jan. 2015, news.donga.com/3/all/20150107/68946868/1. Accessed 7 June 2017.

Jang, Yeon-ok. Korean P'ansori Singing Tradition: Development, Authenticity, and Performance History. Scarecrow, 2014.

Jeon, Sung-Hee. "The Study of National Changguk Company." Minsokhaksuljaryochongseo [Study of Traditional Culture Series] vol. 215: Changguk 3. Urimadang Tuh, 2002, pp. 359-430.

Jung, Dong-kwon. "[TV Chosun Exclusive] Blue House Senior Secretary Jong-beom Ahn Supported 50 Billion Won Fundraising for Culture Foundation MI-R." TV Chosun. 26 July 2016, news.tvchosun.com/site/data/html_dir/2016/07/26/2016072690265.html. Accessed 1 Oct. 2017.

Kang, Yoshik. Geun-hye Park, Korea's First Female President. Midas Books, 2012.

Kim, Bo-eun. "President's ' 7 Missing Hours' Still Shrouded in Mystery." The Korea Times. 22 Nov. 2016, www.koreatimes.co.kr/www/news/nation/2016/11/116_218732.html. Accessed 9 June 2017.

Kim, Chong-chol, "Some Views on the Evolution of Changguk." Korea Journal, vol. 37, no. 2, 1997, pp. 84-99.

Kim Il-song. "Ms. President, Take Your Lesson from Macbeth." Hankyore. 22 Dec. 2016, www.hani.co.kr/arti/opinion/column/775767.html. Accessed 22 July 2017.

Kim, Man-soo. "Problems in Creating Changguk Scripts for the Promotion of Popularity." Minsokhaksuljaryochongseo [Study of Traditional Culture Series] vol. 215: Changguk 3. Urimadang Tuh, 2002, pp. 177-88.

Kim, Ui-kyum, and Ee-kun Ryu. "[Exclusive] Soon-sil Choi Told President Park What to Do." Hankyoreh. 25 Oct. 2016, www.hani.co.kr/arti/politics/politics_general/767209.ht ml\#csidx50211284226b77d8d542ea43f32a9cf. Accessed 9 June 2017.

Kim, Se-jeong. "Choi Soon-sil Family's Enormous Wealth Revealed.” The Korea Times. 6 Mar. 2017, www.koreatimes.co.kr/www/nation/2017/03/251_225168.html. Accessed 15 July 2017.

Knights, L.C. "Macbeth: A Lust for Power." William Shakespeare's Macbeth, edited by Harold Bloom. Chelsea House Publishers, 1987, pp. 39-57.

Ko, Bum-joon. “Tae-sook Han's Changguk Lady Macbeth, 'a Risky Venture.” NEWSIS. 16 Dec. 2016, mobile.newsis.com/view.html?ar_id=NISX20161216_0014586909\#imadnews. Accessed 8 July 2017.

Ko, Mi-hye. "A 2007 American Embassy Document Reports 'Tae-min Choi Is Dubbed a Korean Rasputin." Yonhap News. 28 Oct. 2016, www.yonhapnews.co.kr/bulletin/2016/1 o/28/0200000000AKR20161028057200009.HTML. Accessed 7 June 2017.

Lee, Bo-bae. "Prosecutor Young-soo Park Says, 'Investigation Had Luck, Harsh Criticisms on the Investigation Are Unfair." Yonhap News. 3 Mar. 2017, news.naver.com/main/ read.nhn? mode $=$ LSD\&mid $=$ shm\&sid $1=100 \&$ oid $=001 \&$ aid $=0009079941$. Accessed 7 June 2017. 
Lee, Jung-eun, and Sun-young Kim. "Rehearsal Scene of National Gugak Center's Changguk Lady Macbeth." Auditorium: Monthly Music and Performing Arts Magazine, www.gaeksuk.com/atl/view.asp?a_id=2028. Accessed on 14. July 2017.

McCoy, Richard C. “The Grace of Grace' and Double-Talk in Macbeth." Shakespeare Survey vol. 57: Macbeth and Its Afterlife, edited by Peter Holland. Cambridge UP, 2004, pp.27-37.

Newsis. "[Sewol Disaster] Surviving Families Visit Blue House Wailing 'Please Understand How the Parents Feel." Jejudomin Daily. 9 May 2014, www.jejudomin.co.kr/news/ articleView.html?idxno=50539. Accessed 8 Nov. 2017.

Paek, Hyun-mi. Hankook Changguksa Yeongu [A Study of Korean Changguk]. Taehaksa, 1997.

Pavis, Patrice. "Intercultural Theatre Today (2010)." Forum Modernes Theater, vol. 25, no. 1, 2010, pp. 5-15.

Pavis, Patrice, editor. The Intercultural Performance Reader. Routledge, 1996.

Pihl, Marshall R. The Korean Singer of Tales. Harvard UP, 1994.

Reyes, Maria Luisa Torres. "Multicultural Bildungsroman: Coming of Age between Han and Sana." Kritika Kultura, vol. 28, 2017, pp. 147-89.

Shim, Jung-Soon. "Female Trance in Han Tae-Sook's Production of Lady Macbeth." New Theatre Quarterly, vol. 25, no. 1, 2009, pp. 63-71.

Song, Min-sook. "Director Han Tae-sook's Continuous Endeavor: Moolee's Lady Macbeth." Performance \& Theory, vol. 29, 2008, pp. 168-73.

Song, Tae-hyung. "A 'Changguk' with Little Pansori: Superb Acting, but a Question Mark on Music." Korea Economic Daily. 28 Dec. 2016, news.hankyung.com/ article/2016122810041. Accessed 22 July 2017.

Willoughby, Heather. "The Sound of Han: P'ansori, Timbre and a Korean Ethos of Pain and Suffering." Yearbook for Traditional Music, vol. 32, 200o, pp. 17-30.

Yeo, Yujin, et al. "A Study of Social Cohesion and Social Mobility in Korea with Policy Recommendations (Report No. 2015-25)." Korea Institute for Health and Social Affairs. Dec. 2015, www.kihasa.re.kr/web/publication/research/view.do?pageIndex=9\&keyField $=\&$ key $=\&$ menuId $=44 \&$ tid $=71 \&$ bid $=12 \&$ division $=001 \&$ ano $=2004$. Accessed 17 July 2017.

Yoo, Youngdae, "Characteristics of Changguk and Its Popularization." Minsokhaksuljaryochongseo [Study of Traditional Culture Series] vol. 215: Changguk 3. Urimadang Tuh, 2002, pp. 133-43. 